\title{
Management of Critical Challenging Issues Confronting Nigerian Secondary Schools: A Case of Imo State
}

\author{
Ruth O. Anyaogu \\ Faculty of Education, Imo State University, Owerri
}

\begin{abstract}
The study investigated the critical challenges affecting secondary school education and ways to manage the challenges for the realization of secondary school objectives. Descriptive survey design was employed with a total study population of 11,774 teachers comprising male and female from the three zones in Imo State. Stratified random sampling technique was adopted to select. 420 teachers as sample representing $28 \%$ of total population. Two research questions and two null hypotheses guided the study. The instrument for the study was a researcher developed questionnaire titled Management of critical challenging issues confronting Nigerian Secondary Schools (MCCICNSS) with a reliability coefficient value of ' $r$ ' 0.86. Mean and standard deviation were used to answer the two research questions while t-test statistics was used to test the null hypotheses at 0.05 level of significance. 2.50 was mean decision acceptance value. 420 copies of questionnaires were distributed and retrieved. Findings of the study revealed that prevalence of examination malpractice; low quality in takes and poor performance of students, inadequate financing; poor decayed obsolete equipments; explosion increase in the demand for education, lack of essential/basic facilities- (light, water) among others are critical challenges to secondary schools.

The findings of the study equally revealed among others that suspension of erring students and staff; review of secondary education curriculum, adequate funding of schools; orientation and re-orientation of students and teachers are ways to manage the challenges in secondary schools. However, the study revealed that there is no significant difference in the mean responses of male and female teachers on the challenging issues confronting schools and the ways to manage them, the study concluded that an urgent management of the challenges in secondary school education is imperative to rescue education standard from total collapse. Recommendations made included, provisions of basic facilities, funding, teaching and learning materials by the governments.
\end{abstract}

\section{Introduction}

Education in Nigeria is an instrument par excellence for effecting national development. It is the greatest investment that the nation can make for the quick development of its economic, political, sociological and human resources. Osaat [18] defined education as "the process by which the society through schools, colleges universities and other institutions by a morally acceptable manner transmit knowledge, norms, culture, values and skills from generation to generation". To Igwesi, [9]. "Education is a process of cultural transmission and renewal". Presently, education is the biggest industry in Imo state and it touches on every fabric or segment of human endeavours. The three tiers of government in Nigeria (Local government authority, State and Federal) have consistently proclaimed the importance they attach to education as a vehicle for national development. According to Mbayua [12] education is highly rated in Nigeria and so the upsurge in the awareness of the general populace about the importance and value of education. In this direction, parents passionately desire to send their children to better schools at least to secondary school level.

Secondary education is the education children receive after primary education and before the tertiary stage. It is to prepare the individual for useful living within the society and for higher education. In specific term, secondary education according to national policy on education shall:

- provide all primary school larders with the opportunity for education of a higher level, irrespective of sex, social status,

- religious or ethnic background; offer diversified curriculum to cater for the differences in talents, opportunities and

- future roles; provide tube technical knowledge and vocational skills necessary for agricultural, industrial, commercial and economic development [FRN 6].

To achieve the stated goals, National policy on education, [FRN 6] further stated that "secondary education shall be of six years duration, given in two stages: a junior secondary school stage and a senior secondary school stage; each shall be of three years 
duration". According to Ige [8] secondary education is unique in the educational development of a child, being the crucial link between primary schooling, tertiary education and the labour market". Madumere - Obike [11] maintained that the increase in the demand for sophisticated labour force globally, coupled with the growth of knowledge based 'economies, makes an urgent demand on secondary education. In spite of the role of secondary education, Ajayi [3], Omoregie [17] and Adeyemi [1] reported that it is riddled with crises of various dimensions and magnitude all of which combine to suggest that it is at cross road. Management is an act of service of getting work done with the help of other people within a given time limit. It is a technical or scientific decision making process towards achieving set goals in defined system of environment and within a fixed time limit. According to Ogunu [14], management is the effective organization and utilization of the human and material resources in a particular system for the achievement of identified objectives. He further defined it as a social process which is designed to ensure the co-operation, participation, intervention and involvement of others in the effective achievement of a given or predetermined objective. Management is an administration process established in order to achieve organizational objectives. It is the process of forecasting, planning, organizing, directing, reporting, budgeting and coordinating all efforts for the achievement of identified objectives [16].

\section{Empirical Study}

Some related studies to this research work have been conducted by other researchers from different parts of the country-Nigeria and the world among who are: Ige [8] in Ondo State, Ekundayo [5] in Ado-Ekiti State. Ige [8] carried out a study on "Provision of secondary education in Nigeria: Challenges and way forward" in Akure, Ondo State Nigeria. The population of his study comprised all the principals, Vice-principals and executives of parent's teachers association (PTA) in all the public secondary schools in the state. No sampling was carried out from the population because of their manageable number which is 480. A research questionnaire titled (PSENCWF) was used to collect data from the respondents. The questionnaire had two sections, A and B: section A dealt with the background information of the respondents while section B contained three clusters with 21 items used to elicit information form respondents. A modified likert four point scale was provided for the respondents to indicate the strength of their opinion as follows. Strongly Agree (SA) Agree, (A) disagree (D) and strongly disagree (SD). The instrument was validated by three experts in educational administration and planning and another two in measurements and evaluation from Achievers University, Owo Ondo State. Their corrections and inputs were incorporated into the final draft of the instrument. To ensure the internal consistency of the instrument or instruction, a trial test was established using Cronback Alpha statistics. An overall reliability coefficient of 0.82 obtained indicate that the instrument was reliable. The researcher employed the services of six trained research assistants who were teachers from each of the six education zones in the state. All the 480 questionnaires administered were successfully retrieved and analyzed for the study. Mean scores were employed in answering the research questions. A mean score of 2.50 and above was considered accepted while any item with mean score below 2.50 was rejected. In his findings, Inadequate and decay infrastructural facilities, low quality and inadequate teachers, Unwholesome practices of teachers such as (absenteeism from school and classes, late coming to school, nonkeeping of records, trading within and outside school, immoral relationship with female student's, extortion of money from students, examination malpractice); Students indiscipline act (truancy, stealing, beating and extortion of money from junior ones, disobedience to teachers, smoking, indecent dressing); Poor academic performance of student's in core subject areas (English language, mathematics and sciences); Wastage incidences, etc. On moving secondary education forward the under-listed suggestions were made based on the findings:

- Adequate funding of education in line with the UNESCO (2006), recommendation of $26 \%$ of the gross domestic product (GDP).

- Reprimanding of teachers and students who contravene school rules and regulations;

- Recruitment and training of teachers;

- Regular review of school curriculum in line with changes in the society, etc.

\section{The Problem}

The growing rate of students failures in West African Secondary School Certificate Examination (WASSCE) has injected worry into the minds of all those who have concern for Nigerian youths. In a state or country where a greater number of youths are school dropouts, social vices such as armed-robbery, rapping, cultism, kidnapping and others will be on the increase. Some products of today's secondary education system can neither usefully live in the society nor move into higher institution without their parents aid or forgery. They cannot think for themselves or respect the views and feelings of others. They do not value the dignity of labour except for things that will give them quick money. They want better life hence the Oversea migration syndrome. There are fears that illiterate population of youths can be a fertile ground for terrorists, fanatics, miscreants and tribalists who can be manipulated by 
disgruntled elements to ferment and ignite great havoc in society. Evidence abound where secondary school leavers cannot make a correct sentence in English language, the nation's Lingual Franca or writing a sentence without spelling errors. Adeyemi [1] aptly confirmed the statement when he stated that secondary school system is in a state of despair as indicated by the mass failure of students in core subjects like English language and Mathematics in West African Examination Council (WAEC).

Assessing the student in all activities in the cognitive, affective and psychomotor domains lives one in doubt on the achievement of secondary school education goals as stated by the national policy on education FGN [6]. The rise of materialism, ostentatious display of wealth and pleasure may have overwhelmed educational and moral values. The present Universal Basic Education (UBE) of the nation has increased enrolment into secondary schools but the standard of education is failing year by year. It is against this background that the researcher delved into investigation to find out the challenges that are confronting secondary school education system with a view to finding a way forward in terms of proper management.

\section{Research Question}

The following research questions guided the study:

- What are the challenges confronting public secondary schools in Imo State?

- In what ways can the challenges confronting secondary schools in Imo State be in managed?

\section{Hypothesis}

Two null hypotheses were formulated to guide the study.

$\mathrm{Ho}^{1}$ : There is no significant difference in the mean ratings of male and female secondary school teachers on the challenges confronting public secondary schools in Imo State.

$\mathrm{Ho}^{2}$ : There is no significant difference in the responses of male and female secondary school teachers on the ways of tackling the challenges confronting the school.

\section{Methodology}

The study adopted a descriptive survey design. This method was used because it involves the assessment of teacher's opinions and believe using the questionnaire method Gilbert [7]. The study was carried out in the three education zones of Imo State namely: Owerri zone, Okigwe and Orlu zones. The population comprises all the 11,774 teachers in Imo state secondary schools (4,730 male and 7,044 female teachers). The sample size of 420 respondents obtained by using the stratified random sampling technique represents $28 \%$ of the total population.

A questionnaire titled management of challenging issues confronting Nigerian secondary schools (MCCICNSS) was developed by the researcher as an instrument for data collection for the study. The questionnaire had two sections. Section A contained the background information of the respondents while section B contained 30 items built on two clusters. Cluster A addressed the issue of challenges in secondary schools and cluster B addressed the way the challenges can be managed or solved. The items were structured on a modified likert four point scale of strongly Agree (SA); Agree (A); Disagree (D) strongly disagree (SD) with 4, 3, 2 and 1 point respectively. The instrument was face and content validated by three experts in test construction. Two experts from department of Social Science Education and one expert from measurement and evaluation department all in the faculty of education, Imo State University, Owerri. The instrument was validated with respect to language, comprehensives, contents relevance and clarity of the items. Their suggestions and corrections were incorporated into the final draft of the instrument. A reliability of the instrument was established using Cronback Alpha method. An overal reliability coefficient of 0.87 obtained was considered appropriate for the study. Instrument for the study was administered and collected back by the researcher with the help of research assistants whom were instructed on how to administer and collect the instrument to ensure maximum return of the instrument. All the 420 copies administered were completed, returned and analyzed for the study. Mean and standard deviation statistics were used to answer the research questions while t-test statistics was used to test the null hypotheses at $\mathrm{p}<0.05$ level of significance. A mean of 2.50 and above was adopted as the criterion point for accepting or rejecting the means score.

\section{Results and Finding}

\section{Research question 1}

What are the challenges confronting Secondary school education in Imo State Nigeria?

\section{Research Question 2}

In what ways can the challenges confronting secondary schools in Imo State be managed? 
Table 1. Mean Scores and Standard Deviation on challenges in secondary Schools

\begin{tabular}{|l|l|l|l|l|}
\hline S/No & \multicolumn{1}{|c|}{ Items } & \multicolumn{1}{|c|}{ X } & \multicolumn{1}{|c|}{ SD } & Decision \\
\hline 1. & Lack of effective leadership co-ordination and control & 2.90 & 0.91 & Accepted \\
\hline 2. & Inadequate and low quality teachers & 2.95 & 0.90 & Accepted \\
\hline 3. & Poof decayed obsolete learning equipment & 3.27 & 0.64 & Accepted \\
\hline 4. & Negative attitudes of teachers & 2.98 & 0.90 & Accepted \\
\hline 5. & Indiscipline of students & 3.12 & 0.73 & Accepted \\
\hline 6. & Low quality in takes and poor academic performance of students & 3.29 & 0.61 & Accepted \\
\hline 7. & Prevalence of examination malpractice & 3.58 & 0.78 & Accepted \\
\hline 8. & Inappropriate curriculum & 2.43 & 1.05 & Rejected \\
\hline 9. & Poor and infrequent inspection and supervision of schools & 3.02 & 0.77 & Accepted \\
\hline 10. & Inadequate financing & 3.28 & 0.67 & Accepted \\
\hline 11. & Lack of school libraries & 2.54 & 0.93 & Accepted \\
\hline 12. & Lack of essential/basic facilities -water, light, toilets etc. & 3.25 & 0.09 & Accepted \\
\hline 13. & Poor maintenance of school plant buildings and premises & 3.20 & 0.70 & Accepted \\
\hline 14. & Lack or shortage of instructional materials and teaching aids & 3.23 & 0.62 & Accepted \\
\hline 15. & Shift in school calendar & 1.36 & 0.54 & Rejected \\
\hline 16. & Shortage of school furniture for students and teachers & 2.78 & 0.47 & Accepted \\
\hline 17. & Overcrowded classrooms, labortatory and workshop & 3.07 & 0.47 & Accepted \\
\hline 18. & Explosion increase in the demand for education & 3.25 & 0.69 & Accepted \\
\hline 19. & The unemployment of the secondary school leavers & 2.52 & 0.96 & Accepted \\
\hline 20. & Changes in education polices & 1.38 & 0.58 & Rejected \\
\hline & Total mean & 57.40 & 14.01 & \\
\hline & Average mean & 2.87 & 0.70 & \\
\hline
\end{tabular}

Table 2 Mean scores and standard deviation on ways to manage the challenges in the secondary schools

\begin{tabular}{|l|l|c|c|c|}
\hline $\mathbf{S} / \mathbf{N}$ & \multicolumn{1}{|c|}{ Items } & X & SD & Decision \\
\hline 1. & Uprooting examination malpractice & 3.12 & 0.17 & Accepted \\
\hline 2. & Adequate funding of education, particularly secondary education & 3.22 & 0.87 & Accepted \\
\hline 3. & $\begin{array}{l}\text { Recruitment, training of addition teachers and re-training of serving teachers } \\
\text { (old ones) }\end{array}$ & 3.11 & 0.63 & Accepted \\
\hline 4. & Regular and effective inspection of secondary schools. & 3.02 & 0.77 & Accepted \\
\hline 5. & Suspension of erring students and teachers as an deterrent to others & 3.29 & 0,61 & Accepted \\
\hline 6. & $\begin{array}{l}\text { Compulsory attendance of teachers and students to morning assemblies and } \\
\text { moral instructions }\end{array}$ & 2.95 & 0.92 & Accepted \\
\hline 7. & $\begin{array}{l}\text { Orientation and re-orientation of new and old students as well as teachers on } \\
\text { rules and regulations giving the school }\end{array}$ & 3.25 & 0.71 & Accepted \\
\hline 8. & $\begin{array}{l}\text { Review of secondary education curriculum towards practical and creativity } \\
\text { oriented }\end{array}$ & 3.24 & 0.70 & Accepted \\
\hline 9. & Effective guidance and counseling at students for education and choice of career & 3.20 & 0.73 & Accepted \\
\hline 10. & Paying of stipend to secondary school student's & 2.14 & 1,04 & Rejected \\
\hline & Total mean & 30.54 & & \\
\hline & Average mean & 3.05 & & \\
\hline
\end{tabular}

Table 1 revealed that 17 out of 20 items are accepted as challenges confronting secondary school education in Imo State as their mean scores are above the criterion mean of 2.50. However, items 8,15 and 20 obtained mean scores below the cut-off mean 2.50 .

The average mean of 2.87 indicates an acceptance level. In Table 2 analysis, 9 out of the 10 items identified as ways to manage the challenges in secondary school obtained mean scores above criteria mean surprisingly item 10 (paying of stipend to secondary school students) obtained mean score of 2.14 which is below the cut-off mean (2.50).

\section{Hypothesis 1}

There is no significant difference in mean ratings scores of male and female teachers on the challenges confronting state secondary schools in Imo state. 
Table 3. T-test analysis on challenges in secondary schools as rated by male and female teachers

\begin{tabular}{|l|l|l|l|l|l|l|l|l|}
\hline Respondents & N & $\mathbf{X}$ & SD & Df & t-cal & t-crit & Probability & Decision \\
\hline Male teachers & 200 & 2.0 & 1.45 & & & & & $\mathrm{H}_{\mathrm{o}}$ \\
\hline & & & & 418 & 0.29 & 1.96 & 0.05 & Accepted \\
\hline Female teachers & 220 & 2.0 & 1.45 & & & & & \\
\hline
\end{tabular}

Table 4: t-test analysis on the mean rating scores of male and female teachers on the ways to manage the challenges in secondary schools in Imo State

\begin{tabular}{|l|l|l|l|l|l|l|l|l|}
\hline Respondents & $\mathbf{N}$ & $\mathbf{X}$ & SD & df & t-cal & t-crit & Probability & Decision \\
\hline Male teachers & 200 & 3.36 & 1.83 & & & & & $\mathrm{H}_{\mathrm{o}}$ \\
\hline & & & & 418 & 0.07 & 1.96 & 0.05 & Accepted \\
\hline Female teacher & 220 & 3.34 & 1.83 & & & & & \\
\hline
\end{tabular}

\section{Hypothesis 2}

There is no significant difference between the mean ratings of male and female teachers on the ways to manage the challenges confronting secondary schools in Imo State.

Table 4 showed that the $t$-calculated of 0.07 was obtained at 0.05 significance level and 418 degree of freedom. The calculated $t$ value is less than the table value of 1.96. Therefore the null hypothesis is accepted. This implied that there was no significant difference between the mean ratings score of male and female teacher's on the ways to manage the challenging issues in the secondary schools in Imo State.

\section{Discussion of Findings}

In Table 1, 20 items were presented to the respondents and 17 out of the 20 obtained scores above the cut-off mean, indicating that the items are challenging issues confronting secondary schools education in Imo State. Nevertheless, they disagreed with items 8,15 and 20 with mean score 2,43, 1.36 and 1.38 respectively. This implied that inappropriate curriculum, shift in school calendar and changes in education policies do not pose a challenge to secondary schools education. This agreed with Ekundayo [5] who asserted that inadequate funding, inadequate facilities, low staff morale, poor supervision of schools are some of the problems bedeviling secondary schools which have been hindering the system from achieving its lofty goals. In the same vein, this finding is in agreement with Ogakwu [13] who stated that examination malpractice, indiscipline, shortage of trained teachers, shortage of instructional materials inadequate financing, explosive increase in the Table 3 showed that $\mathrm{t}$ cal. is 0.29 at 418 degree of freedom and 0.05 level of significance.

Since the t calculated value of 0.29 is less than tcritical of 1.96, the null hypothesis of the study stands accepted. This indicates that there is no significant difference between the mean ratings of male and female teachers on the challenges facing secondary schools education in Imo State.

Demand for education are issues and challenges facing education in Nigeria. Table 2 revealed that nine out of ten items obtained mean sores above the 2.50 cut-off mean. This implied that teachers agreed that uprooting examination malpractice, adequate funding, recruitment, training and re-training of teachers, regular inspection, suspension of erring students and teachers, attendance to morning assemblies and moral instructions, orientation and reorientation of old and new students review of curriculum toward practical and creativity, and effective guidance and counseling of students for education and career choices are ways to tackle the challenges confronting secondary schools in Imo State. Item 10, paying stipend to secondary students was rejected. This finding is in consonance with Ige [8] who stated that curbing examination malpractice, adequate funding, effective administration of secondary school, recruitment and training of additional teachers, commitment and effectiveness of teachers, curbing wastage in secondary education review of secondary education curriculum are among the ways to move secondary education, forward in Nigeria. On the other hand the finding did not agree with the present practice under taking by state government by giving a paltry sum of one hundred naira (N100 equivalent to 48 pence) to student as stipends monthly. Null hypothesis one revealed that there is no significant difference between the mean rating of male and female teachers on the challenging issues confronting secondary education. Equally, the null hypothesis two was accepted. This is based on the ground that t-calculated (0.07) did not exceed the t-critical (1.96). This is an indication that both male and female teachers shared the same view on the ways to manage the challenges confronting secondary schools. These findings agreed with Awodun [4] who noted that sex differentiation is not a factor in educational assessment. 


\section{Implication of the Study to Secondary School Management}

The findings of the study have implications for secondary school administration. The finding revealed that negative attitude of teachers is one of the major challenges affecting the school system. According to Ekundayo [5] Okem [15] and Ihebereme and Anyaogu [10] secondary schools can only be productive, if there is effective and efficient management of human and material resources in the system by the teachers. For proper discipline in schools, success of students, improvement on the fallen standard of education, teaching and learning and achievement of national goals for secondary school education system, the teachers need to stand on their feet, for no education can rise above the level of her teachers. Teacher's management of the challenging issues in secondary schools is imperative. It will be regarded as an effort in futility if secondary school leavers are found wanting in their entry qualifications for tertiary institutions or helping themselves with the knowledge acquired in the secondary school.

\section{Conclusion}

Urgent management of the challenging issues bedeviling secondary school education in Imo State is imperative since education is her biggest industry. A fall in educational standard could result to a fall in development and standard of living. Education is a very complex industry. To tackle the challenges plaguing secondary schools, administrators, parent and the government have roles to play towards ensuring that the challenges are combated and that secondary education is moved forward, from its status quo.

\section{Recommendations}

Based on the findings of this study, the following recommendations were made.

1. The teachers, who are the fulcrum of education reform, should be more committed to duty to ensure that the challenges are managed effectively and that secondary education is moved forward, to its former status quo before the civil war.

2. The government should match her formidable secondary school education goals with adequate fund, adequate basic necessities (water, light) teaching and learning materials, equipments etc.

3. The government, teachers, parents host community and all stakeholders in education should join hands to manage and fight the indiscipline and examination malpractice racking schools presently else students can degenerate and become street miscreants. Education for all should be a concern to all. As such adequate arrangement must be made for the provision of necessary facilities, infrastructure, funds, quality teachers etc.

4. The modern-day principals should be knowledgeable, professionally and administratively competent, as well as resourceful so as to complement the effects of the government towards achieving the goals of the schools.

5 . The school managers or administrators should be encouraged and sponsored to attained seminars, workshops, conferences especially international conferences on education for exchange of ideas. This will serve as a means for professional growth, injection of innovation in school system as well as moral boast and incentives to the principals.

\section{References}

[1] Adeyemi, T. O. (2008). Predicting Students' Performance in Senior Secondary Certificate Examination from Performance in Junior Secondary School Certificate in Ondo State, Nigeria. Humanity and Social Science Journal 3 (1): pp 26-36.

[2]Adeyemi, T. O. (2012) School variables and internal efficiency of secondary schools in Ondo state. Nigeria Journal of Nigeria. Educational Sociology Resources 2 (3) pp 204-214.

[3] Ayayi, I. A. ((2002) Resource factors as correlates of Secondary School Effectiveness in Ekiti State. Nigeria Journal of Counseling and Psychology I (1) pp. 109-115.

[4] Awodun, M. (2005) A Process Approach towards Defining Entrepreneurship. Organization Review, 1 pp (1) 20-25.

[5] Ekundayo, H T. (2010) Administering Secondary Schools in Nigeria for Quality output in the $21^{\text {st }}$ Century: The Principals Challenge. European Journal of Educational Studies 2 (3) pp 187-192

[6] Federal Republic of Nigeria (2004) National Policy on Education Lagos: NERDC Press.

[7] Gilbert, N. (1994) Research in Social Life. London: Saga publication Ltd.

[8] Ige, A. M (2013) Provision of Secondary Education in Nigeria: Challenges and way forward. Journal of African Studies and Development 5 () 19 available online http:www academicjournlas.org/JASD retrieved 2:35pm (20 $0^{\text {th }}$ May 2014).

[9] Igwesi, B. N (2011) Indiscipline in Nigeria Secondary Schools, in Issues and Challenges in Nigeria Education vol. II Lagos West and Solomon Pub. Company Ltd.

[10] Ihebereme C. I. and Anyaogu R. O (2012).A Transformation Approach for Developing Entrepreneurial Instruction in Skills Acquisition by Academic Staff in Imo State Tertiary Institutions. Nigerian Journal of Educational Administration and Planning NAEAP 12 (1) pp 117-130.

[11] Madumere-Obike, C. U (2008) Secondary education in the $21^{\text {st }}$ Century: Management 
Challenges. Multidisciplinary Journal of Research Development Muljore 10 (5) pp 11-17.

[12] Mbayuo, (2011) Issues and Challenges in Nigeria Education in the $21^{\text {st }}$ century. Lagos: west and Solomon Pub. Company Ltd.

[13] Ogakwu, V. N (2011) Issues and Challenges in Nigerian Education in the $21^{\text {st }}$ Century vol. II Onitsha: West and Solomon Publishing Company Ltd.

[14] Ogunu, M. (2001). Introduction to Educational Management. Benin City: Ambix Press Limited.

[15] Okem, B (2009) Entrepreneurship Education in Action: The Unemployment Menace Educational Research Journal 1(I), pp 10-18.

[16] Oku, O. O, Emenalo, F. C. and Okeke, F. N. (2013). Fundamental Issues in Education administration and Supervision. Owerri: Acadapeak Publishers Ltd.

[17] Omoregie, N. (2005). Re-packaging Secondary Education for great and Dynamic Economy. Paper presents at the $2^{\text {nd }}$ Annual National Conference of Association for Encouraging Quantitative Education in Nigeria (ASSEQEN) $9^{\text {th }}-11^{\text {th }}$ May.

[18] Osaat, S. D (2006) Philosophy of Education an Assessment. Port Harcourt: Division Publishers.

[19] UNESCO (2006), UNESCO National Education Support Strategy (UNESS) for Nigeria: 2006-2015. Abuja Government Press. 